\title{
The Voltammetric Behaviour of Lead at a Hand Drawn Pencil Electrode and Its Trace Determination in Water by Stripping Voltammetry Kevin C. Honeychurch
}

\author{
Department of Biological, Biomedical and Analytical Sciences, Faculty of Applied Sciences, \\ University of the West of England, Bristol, UK \\ Corresponding author Tel.: +44 117 3282977. Fax: +44 1173282904 Email: \\ kevin.honeychurch@uwe.ac.uk
}

\begin{abstract}
This is the first reported the proof of concept application of pencil drawn electrodes (PDEs) for anodic stripping voltammetric determination of $\mathrm{Pb}^{2+}$ or any metal ion. PDEs offer advantages of economics, simplicity and rapid fabrication, affording a green alternative for the development of new devices. Cyclic voltammetric investigations of $\mathrm{Pb}^{2+}$ at these electrodes in $0.30 \mathrm{M}$ acetic acid were characterised by a cathodic reduction peak on the initial negative scan resulting from the reduction of $\mathrm{Pb}^{2+}$ ions to $\mathrm{Pb}^{0}$. Anodic peaks obtained on the return positive scan showed that $\mathrm{Pb}$ had been deposited as a thin film on the PDE surface. The addition of $\mathrm{Cl}^{-}$ions to this electrolyte improved the voltammetric behaviour and a supporting electrolyte of $0.30 \mathrm{M}$ acetic acid containing $0.25 \mathrm{M} \mathrm{KCl}$ was found to be optimum. Investigations were made into the possibility of determining trace levels of $\mathrm{Pb}^{2+}$ by differential pulse anodic stripping voltammetry. The effect of accumulation potential and time were investigated and optimised. Three anodic stripping peaks were recorded resulting from the heterogeneous nature of the electrode surface. Using an accumulation potential of $-1.1 \mathrm{~V}$ and an accumulation time of $200 \mathrm{~s}$ a bimodal calibration curve was recorded, with linear ranges between 80 to $330 \mathrm{ng} / \mathrm{mL}$ and 330 to $915 \mathrm{ng} / \mathrm{mL}$. The theoretical detection limit $(3 \sigma)$ was calculated as 9.5 $\mathrm{ng} / \mathrm{mL}$. $\mathrm{Pb}^{2+}$ determinations on a drainage water sample gave a mean recovery of $100.9 \%(\% \mathrm{CV}=$ $5.7 \%)$ at a concentration of $166.1 \mathrm{ng} / \mathrm{mL}$ indicating the method holds promise for the determination of $\mathrm{Pb}^{2+}$ in such samples.
\end{abstract}




\section{Introduction}

Carbon electrodes have are widely used in electrochemistry and are a well-established technology [1]. A number of different carbon based materials and technologies have been commonly utilised such as glassy carbon [2], carbon paste [3] or screen-printed [4]. All of these approaches require some degree of expertise, preparation and care. As a result, a number of alternative sources for the manufacture of carbon electrodes have been investigated, such as the utilisation of pencil leads as electrodes [5-12]. The pencil "lead" is actually a mixture of graphite, wax and clay, the proportions of which impart different properties to the pencil with increasing amounts of clay making the pencil harder, hence the designation ' $\mathrm{H}$ '. Increasing the levels of graphite make the pencil softer, and their marks darker or black and so the designation 'B'. For example, one of the darkest generally available pencils, the $6 \mathrm{~B}$ is $84 \%$ graphite, $10 \%$ clay and $5 \%$ wax, compared to the common, lighter HB, or No. 2 pencil which has a composition of $68 \%$ graphite, $26 \%$ clay and $5 \%$ wax [13]. Commonly, pencils have been used directly as the working electrode itself [5-12], only recently has the possibility of using pencils to draw electrodes and other electronic components onto a suitable substrate been reported [14]. This latter approach has a number of advantages, as designs and geometries can be easily altered as they are simply drawn by hand on to a suitable substrate. This allows for an extremely facile, green, low-cost, rapid method to fabricate electrode prototypes, as illustrated in table 1.

A number of different electrochemical applications including resistors, capacitors, UV and piezoresistive sensors, microfluidic devices, chemiresistive sensors, biosensors, batteries and field effect transistors have been reported [14]. However, there have only been a small number of reports on the application of these devices using voltammetry and until now its application has been generally only in the characterisation of the electrode [15]. Recently, Santhiago and Kubota [16] have developed a glucose biosensor employing paper and a pencil drawn working electrode modified with the mediator 4-aminophenylboronic acid and glucose oxidase (GOD). Hydrogen peroxide formed during the enzymatic reaction of glucose resulted in the oxidation of 4-aminophenylboronic acid to 4aminophenol which was determined voltammetrically at the Pencil drawn electrode (PDE). Dossi et al [17] have also explored the electrochemical behaviour of ascorbic acid, dopamine and paracetamol 
by cyclic voltammetry at their PDEs and have reported well-defined redox behaviour. Thin-layer chromatography was used to separate mixtures of these compounds and co-eluting species could be identified using a dual electrode redox system formed from two in series PDEs. Recently, Santhiago et al [18] have used a 6B pencil to draw a counter electrode as part of a three electrode system for the voltammetric determination of $p$-nitrophenol. However, the system used a pencil lead as the working electrode.

This present study investigates the possibility of using PDEs for the anodic stripping voltammetric (ASV) determination of $\mathrm{Pb}$. This is believed to be the first reported application for such devices for the stripping voltammetric determination of $\mathrm{Pb}^{2+}$ or any other metal ion. The toxicity of $\mathrm{Pb}$ is widely understood, causing a wide range of different conditions, such as: reduced birth weight, vitamin D metabolism interference, learning difficulties [19], reduction in IQ [20], increased hearing threshold [21], hypertension [22,23] and decreased sperm counts [24] and possible mutagenic effects [25]. Lead is also increasingly implicated in dementia in the elderly [26] as levels stored in bone are released into the body due to processes associated with osteoporosis. A link has also been drawn with the levels of violence and antisocial behaviour in society $[27,28]$. As a result, a number of different measures have been undertaken to lower our exposure, such as its removal from petrol, paint and plumbing. Nevertheless, there are still a number of issues with the previous usage of $\mathrm{Pb}$ resulting in a legacy of widespread contamination [29]. Present day Pb blood levels are still between 50 to 200 times greater than the blood $\mathrm{Pb}$ concentrations of preindustrial humans at about $0.8 \mathrm{nM}(0.016 \mu \mathrm{g} / \mathrm{dL})$ [30-32]. Advances in toxicology have highlighted the increasingly smaller concentrations that $\mathrm{Pb}$ is known to cause adverse effects [33,34]. This has shown levels previously thought to be acceptable to be too high. Consequently, there is pressing need to monitor $\mathrm{Pb}$ levels in a range of media. A number of different analytical methods have been utilised, including inductively coupled plasma [35] and atomic adsorption spectroscopy [36], requiring well equipped laboratories, refined gases and high electrical power consumption for their implementation. Electrochemical techniques have been highlighted [4,37] as an alternative method offering a number of advantages. Modern handheld instruments requiring little more than an appropriate power supply and can be even operated under 
battery power alone. One such electrochemical technique, anodic stripping voltammetry, has been shown to be able to gain the low detection limits required [37]. The sensitivity of the assay can be tailored by altering the length of the accumulation step. Short accumulation times, in the order of less than one minute, can be used to determine sub to high ppm levels, with ppb and even sub ppb levels can be determined if the accumulation time is extended.

The aim of this present study was to investigate the possibility of using PDEs for the anodic stripping voltammetric determination of trace concentrations of $\mathrm{Pb}$. The voltammetric behaviour of $\mathrm{Pb}$ at the electrode was first investigated by cyclic voltammetry. The optimum conditions required for the stripping voltammetric determination of $\mathrm{Pb}$ were then identified and finally the possibility of determining trace levels of $\mathrm{Pb}$ in environmental surface waters was explored.

\begin{tabular}{|l|l|l|l|}
\hline Analyte & Fabrication & Analytical Technique & Reference \\
\hline Glucose & $\begin{array}{l}\text { Pencil drawn working } \\
\text { electrode with a Ag ink } \\
\text { pseudo-reference/counter } \\
\text { electrode. }\end{array}$ & $\begin{array}{l}\text { Glucose biosensor. } \\
\text { Working electrode } \\
\text { modified with the } \\
\text { mediator; 4- } \\
\text { aminophenylboronic acid } \\
\text { and glucose oxidase. } \\
\text { Voltammetric } \\
\text { determination of } \\
\text { enzymatically generated } \\
\text { 4-aminophenol }\end{array}$ & {$[16]$} \\
\hline $\begin{array}{l}\text { Ascorbic acid, } \\
\text { dopamine and } \\
\text { paracetamol }\end{array}$ & Pencil drawn dual electrode & $\begin{array}{l}\text { Thin-layer } \\
\text { chromatography used to } \\
\text { separate compound } \\
\text { mixtures. Co-eluting } \\
\text { species could be } \\
\text { identified using dual } \\
\text { electrode redox system }\end{array}$ & {$[17]$} \\
\hline$p$-nitrophenol & $\begin{array}{l}\text { A 6B pencil drawn counter } \\
\text { electrode }\end{array}$ & $\begin{array}{l}\text { Counter electrode as part } \\
\text { of a three electrode } \\
\text { system with pencil } \\
\text { working electrode }\end{array}$ & {$[18]$} \\
\hline $\begin{array}{l}\text { Toluene, THF, } \\
\text { ethyl acetate, } \\
\text { methanol, hexane } \\
\text { to acetone }\end{array}$ & $\begin{array}{l}\text { Chemiresistors hand-drawn on } \\
\text { paper }\end{array}$ & $\begin{array}{l}\text { Solvent vapour measured } \\
\text { at pencil drawn } \\
\text { Chemiresistor }\end{array}$ & {$[38]$} \\
\hline Mechanical strain & $\begin{array}{l}\text { Chemiresistors hand-drawn on } \\
\text { paper }\end{array}$ & $\begin{array}{l}\text { Output voltage for an HB } \\
\text { pencil was found to be } \\
\text { more sensitive than that } \\
\text { for a 9B pencil }\end{array}$ & {$[39]$} \\
hydrogen & $\begin{array}{l}\text { Cysteine and hydrogen } \\
\text { peroxide linear range 0.5- }\end{array}$ & {$[40]$} \\
drawing modified electrodes & Doped pencil leads for & \\
\hline
\end{tabular}




\begin{tabular}{|c|c|c|c|}
\hline peroxide & $\begin{array}{l}\text { on paper. Carbon pencil leads } \\
\text { doped with either } \\
\text { decamethylferrocene or cobalt } \\
\text { (II) phthalocyanine }\end{array}$ & $\begin{array}{l}10 \mathrm{mM} \text { at cobalt (II) } \\
\text { phthalocyanine modified } \\
\text { pencil drawn electrode }\end{array}$ & \\
\hline $\begin{array}{l}\text { Hexacyanoferrate } \\
\text { (II) and 1,2- } \\
\text { hydroxybenzene }\end{array}$ & $\begin{array}{l}\text { Pencil leads doped with } \mathrm{Ag} \\
\text { and } \mathrm{AgCl} \text { drawn on paper to } \\
\text { from } \mathrm{Ag} / \mathrm{AgCl} \text { reference } \\
\text { electrodes }\end{array}$ & $\begin{array}{l}\text { Performance evaluated by } \\
\text { voltammetric } \\
\text { measurements of } \\
\text { hexacyanoferrate(II) and } \\
1,2 \text {-hydroxybenzene as } \\
\text { probe species }\end{array}$ & [41] \\
\hline $\begin{array}{l}\text { Carbohydrate } \\
\text { antigen } 199\end{array}$ & $\begin{array}{l}\text { Entirely hand drawn with } \\
\text { commercially available } \\
\text { crayon and pencils }\end{array}$ & $\begin{array}{l}\text { Linear response range } \\
\text { from } 0.01-200 \mathrm{U} / \mathrm{mL} \text {. } \\
\text { Detection limit of } 0.0055 \\
\mathrm{U} / \mathrm{mL} \text { obtained by } \\
\text { electrochemiluminescence }\end{array}$ & [42] \\
\hline Lead & $\begin{array}{l}\text { 6B pencil drawn carbon } \\
\text { electrode }\end{array}$ & $\begin{array}{l}\text { Anodic stripping } \\
\text { voltammetry }\end{array}$ & This work \\
\hline
\end{tabular}

Table 1. Recent applications of pencil drawn electrodes.

\section{Experimental Section}

\section{Chemical and Reagents}

All chemicals were supplied from Fisher (Loughborough, UK), unless otherwise stated. Lead stock solutions were prepared by dissolving the appropriate mass of $\mathrm{Pb}\left(\mathrm{NO}_{3}\right)_{2}$ in deionised water. Working standards, for optimisation of studies, were prepared by dilution of the primary stock solution with deionised water. Deionised water was obtained from a Purite RO200-Stillplus HP System, (Purite Oxon, UK). Electrolyte solutions for cyclic voltammetric studies were prepared by dilution of glacial acetic acid to give a $0.30 \mathrm{M}$ solution. This was then fortified with sufficient $\mathrm{KCl}$ to give a $0.25 \mathrm{M}$ solution. Environmental water samples were obtained from a rainwater drainage ditch from the Frenchay Campus of the University of the West of England, UK.

\section{Fabrication of Pencil Drawn Sensors}

The sensor was fabricated by drawing of the electrode design onto a $0.5 \mathrm{~mm}$ PVC substrate (Cadillac Plastics, Swindon, UK) with a 6B pencil (Derwent Graphic, UK). A $4 \mathrm{~mm}$ diameter working electrode was drawn with a $10 \mathrm{~mm}$ x $2 \mathrm{~mm}$ connection strip. The working electrode area was defined with dielectric tape (RS Components, Corby, Northamptonshire, UK). The working electrode was then cut from the PVC support and the connecting strip trimmed to $10 \mathrm{~mm}$. The electrode was then 
connected to the potentiostat using a gold clip attached to coaxial cable inserted into the appropriate sockets.

\section{Apparatus}

Cyclic voltammetry, linear sweep anodic stripping voltammetry (LSASV) and differential pulse anodic stripping voltammetry (DPASV) were performed with a Pstat10 potentiostat interfaced to a PC for data acquisition via the General Purpose Electrochemical System Software Package (GPES) version 3.4 (Autolab, Windsor Scientific Limited, Slough Berkshire UK). The cell used for the voltammetric measure ments was obtained from Metrohm (Switzerland); a small magnetic stirrer bar was placed in the bottom of the cell for stirring in the pre-concentration step of DPASV. This was rotated at a fixed constant rate by a rotary stirrer (Mini MR Stirrer, Whatman, Maidstone, Kent, UK). All measurements were made using the PDE was the working with a saturated calomel reference (Russell, UK) electrode and a graphite rod counter electrode.

\section{Cyclic voltammetry}

Cyclic voltammograms were initially recorded with plain solutions of $0.30 \mathrm{M}$ acetic acid, containing $0.25 \mathrm{M} \mathrm{KCl}$ and then in the same solution containing $0.1 \mathrm{mM} \mathrm{Pb}$. Degassing was achieved by purging with oxygen free nitrogen (BOC, Guildford, UK) for 5 minutes to eliminate oxygen reduction waves. A starting and end potential of $0.0 \mathrm{~V}(v s$. SCE) was used, with a switching potential of $-1.5 \mathrm{~V}$ (vs. SCE) and a scan rate of $50 \mathrm{mV} / \mathrm{s}$.

\section{Differential Pulse Anodic Stripping Voltammetry}

Accumulation was carried out for $200 \mathrm{~s}$ at $-1.1 \mathrm{~V}$ (vs. SCE). Initially, the stripping voltammogram was recorded using linear sweep voltammetry using a scan rate of $50 \mathrm{mV} / \mathrm{s}$. Further studies were made by DPASV using a step height of $10 \mathrm{mV}$, pulse repetition time $0.2 \mathrm{~s}$, pulse amplitude of $50 \mathrm{mV}$, and pulse duration of $50 \mathrm{~ms}$. The stripping voltammogram was recorded over the potential range -1.1 $\mathrm{V}$ to $0.0 \mathrm{~V}$ (vs. SCE).

\section{Scanning Electron Microscopy}

Scanning electron microscopy was undertaken using a Philips XL30 ESEM system. 


\section{Results}

\section{Scanning Electron Microscopy}

Scanning electron microscopy (SEM) (Figure 1) investigations showed the surface of the PDE to be heterogeneous in nature showing good coverage of the underlying PVC substrate. The topography of the electrode surface would seem to follow the underlying PVC substrate. This is similar to that seen by Lin et al [38] in studies undertaken on paper substrates. Further investigations showed a mean resistance of $1.9 \mathrm{k} \Omega(\% \mathrm{CV}=2.53 \%)$ was obtained for ten PDEs.

\section{Cyclic Voltammetry}

Figure 2 shows a typical cyclic voltammogram obtained for $0.1 \mathrm{mM} \mathrm{Pb}$ solution at the PDE with a supporting electrolyte of $0.3 \mathrm{M}$ acetic acid in the presence and absence of $\mathrm{Cl}^{-}$ions. In the absence of $\mathrm{Cl}^{-}$the resulting voltammograms exhibited one cathodic peak on the forward negative going scan and two anodic peaks on the return positive scan. The cathodic peak results from the deposition of $\mathrm{Pb}^{2+}$ ions from solution to the electrode surface with the subsequent anodic peak resulting from the stripping of different layers of $\mathrm{Pb}$ metal film adsorbed at the electrode surface. These studies suggest the possibility of using these PDEs for the determination of $\mathrm{Pb}$ using anodic stripping voltammetry, the formation of such adsorbed layers is necessary for the accumulation step.

In previous studies at carbon electrodes the addition of $\mathrm{Cl}^{-}$ions to the supporting electrolyte has been shown to greatly improve the voltammetric behaviour of metal ions such as $\mathrm{Pb}$ [43-45]. Further cyclic voltammetric investigations showed that the addition of $\mathrm{Cl}^{-}$ions to the $0.3 \mathrm{M}$ acetic acid supporting electrolyte solution resulted improved peak shapes and lower $\Delta$ Ep values. Figure 2 shows the resulting improvement obtained by the addition of $0.25 \mathrm{M} \mathrm{KCl}$. Consequently, further studies were undertaken using supporting electrolyte solution of $0.3 \mathrm{M}$ acetic acid $0.25 \mathrm{M} \mathrm{KCl}$.

\section{Effect of Accumulation Potential}


Linear sweep voltammetry was used to investigate the effect of applied potential was studied for a 0.1 $\mathrm{mM} \mathrm{Pb}^{2+}$ solution over the range $-0.55 \mathrm{~V}$ to $-1.3 \mathrm{~V}$ (vs. SCE) using an accumulation time of $15 \mathrm{~s}$ in still solution. Under these conditions, the magnitude of the stripping peak was found to increase with increasing negative potential, until forming a plateau between $-1.0 \mathrm{~V}$ and $-1.3 \mathrm{~V}$ (vs. SCE) (Figure 3). Consequently, further investigations were made using an applied potential of $-1.1 \mathrm{~V}$ (vs. SCE).

\section{Effect of Voltammetric Waveform}

In previous investigations we have shown the improved analytical performance that can be gained by using the differential pulse waveform compared to linear sweep voltammetry [46]. Figure 4a shows a typical LSV obtained for $415 \mathrm{ng} / \mathrm{mL} \mathrm{Pb}$ using an accumulation time of $120 \mathrm{~s}$. This resulted in poor analytical performance, with a small peak at $-0.56 \mathrm{~V}$ on a sloping baseline recorded. However, using the same accumulation potential and time, three well-defined stripping peaks for $\mathrm{Pb}$ were obtained by differential pulse voltammetry (Figure 4b). The small voltammetric responses seen in the absence of $\mathrm{Pb}$ are believed to result from the heterogeneity of the electrode surface. Consequently, further investigations were made using this waveform.

\section{Effect of Accumulation Time}

As it was intended to use these PDEs for the determination of low concentrations of $\mathrm{Pb}^{2+}$, further studies were undertaken to ascertain the effect of accumulation time using an applied potential of -1.1 $\mathrm{V}(v s . \mathrm{SCE})$ for a $415 \mathrm{ng} / \mathrm{mL} \mathrm{Pb}^{2+}$ solution in the optimised electrolyte. Figure 5 shows the resulting effect of accumulation time on the peak current $\left(i_{\mathrm{p}}\right)$. Peak currents for all three (i, ii and ii) anodic $\mathrm{Pb}$ stripping peaks were found to increase with time. Peak current of peak (i) was found to be the most sensitive, and a linear relationship with time was found up to $240 \mathrm{~s}$. Beyond this time ip continued to grow but exhibited a quasi-linear relationship. Both the anodic peaks (ii) and (iii) showed a similar behaviour, but were found to be less sensitive and as a result further analytical investigations were made using peak (i).

The formation of multiple stripping peaks has been previously reported at solid electrodes [37,46,47]. The extra peaks (ii and iii) with more positive peak potential (Ep) values than the main peak (i) are believed to result from stripping of the first monolayer of $\mathrm{Pb}$ bound to the electrode surface with the 
greatest energy compared to the bonding of subsequent layers. The greater bounding energy consequently requires greater energy, resulting in increased positive potentials required for their stripping. The heterogeneous nature of the electrode surface results in the appearance of more than one of these extra peaks results from the bounding energy of this monolayer being different from siteto-site on the electrode surface.

\section{Calibration Studies by Differential Pulse Anodic Stripping Voltammetry}

A calibration study was performed on standard $\mathrm{Pb}^{2+}$ solutions over the range $83 \mathrm{ng} / \mathrm{mL}$ and 915 $\mathrm{ng} / \mathrm{mL}$ using a deposition potential of $-1.1 \mathrm{~V}$ and deposition time of a $200 \mathrm{~s}$ (Figure 6). It was found that two different calibration ranges were obtained over the range studied. The slope between 83 and $330 \mathrm{ng} / \mathrm{mL}$ was $1.06 \mathrm{nA} / \mathrm{ng} / \mathrm{mL}$ and between 330 and $915 \mathrm{ng} / \mathrm{mL}$ was $1.80 \mathrm{nA} / \mathrm{ng} / \mathrm{mL}$. This behaviour may be explained by a change in the way the multilayer of $\mathrm{Pb}$ is deposited above some critical thickness [37,46,47]. Such behaviour has been reported at graphite electrodes and is indicative of the deposition of metals, such as $\mathrm{Pb}$ on carbon substrates $[37,46]$.

\section{Analytical Application}

The PDEs were evaluated by carrying out $\mathrm{Pb}$ determinations on drainage water obtained from University of the West of England, UK. A $5 \mathrm{~mL}$ aliquot of the sample was diluted with sufficient acetic acid and $\mathrm{KCl}$ solution to give a $10 \mathrm{~mL} 0.3 \mathrm{M}$ acetic acid/0.25 M KCl. The deposition time and potential, as well as DPASV parameters were the same as used previously. The concentration of $\mathrm{Pb}$ was determined using the method of multiple standard additions and Figure 7 shows the effect of added standards to a typical drainage water sample. Table 2 shows the precision and recovery data obtained for the drainage water sample. These data demonstrate that the proposed method has promise for the determination of $\mathrm{Pb}$ in such water samples.

\section{Conclusion}

This proof of concept study has shown pencil drawn electrodes to be low-cost, simple and rapid to fabricate and green. The redox behaviour of $\mathrm{Pb}$ at pencil drawn electrodes was investigated. Welldefined cathodic and anodic peaks could be obtained utilising an electrolyte comprising of $0.30 \mathrm{M}$ 
acetic acid, $0.25 \mathrm{M} \mathrm{KCl}$. By using a deposition potential of $-1.1 \mathrm{~V}$ it was demonstrated that these electrodes could be used in conjunction with DPASV for the trace determination of $\mathrm{Pb}$ with only simple dilution of the sample with supporting electrolyte.

The PDEs could be successfully used for the DPASV determination of low $\mathrm{Pb}$ concentrations comparable to those reported in a number of environmental water samples $[48,49]$ without the need for further modification. The present study utilised a deposition time of only $200 \mathrm{~s}$. Consequently, it should be possible to enhance the sensitivity of the assay significantly by extending this parameter. It should then be possible to obtain detection limits similar to those obtained at other conventional electrode materials $[50,51]$.

It is envisaged that further work will be performed to develop these PDEs for trace detection of other metal pollutants. Demonstrable improvements in selectivity have been reported using either the in situ or ex situ deposition of metal thins of $\mathrm{Bi}$ [50], $\mathrm{Hg}$ [51] or Sb [52]. Consequently, it is believed that a similar approach could be employed with these devices.

\section{Acknowledgements}

I am grateful to the University of the West of England. David Patton is thanked for his assistance with the SEM analysis. 
Figures and Tables

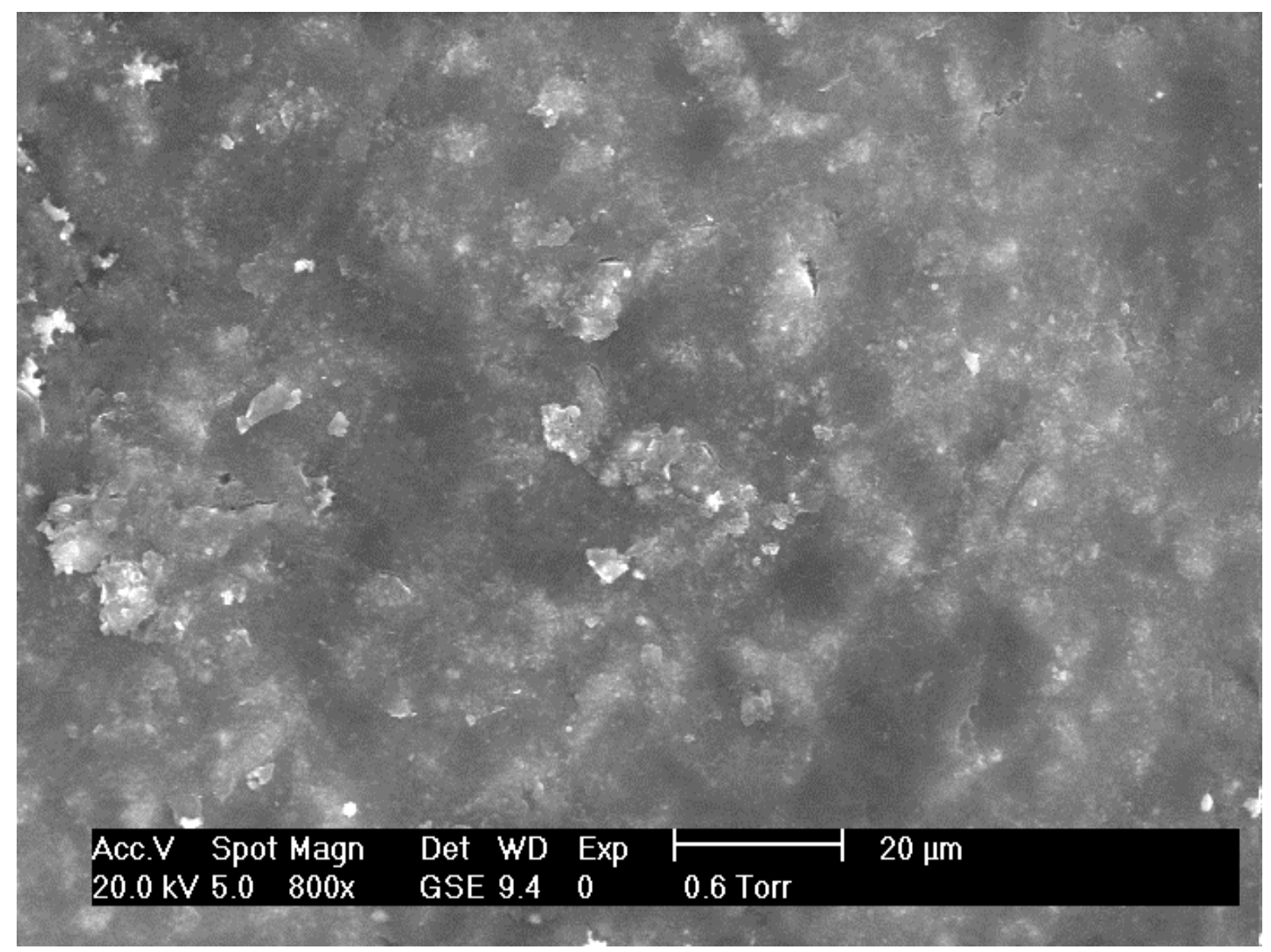

Figure 1. SEM image of a 6B pencil drawn electrode on PVC substrate. 


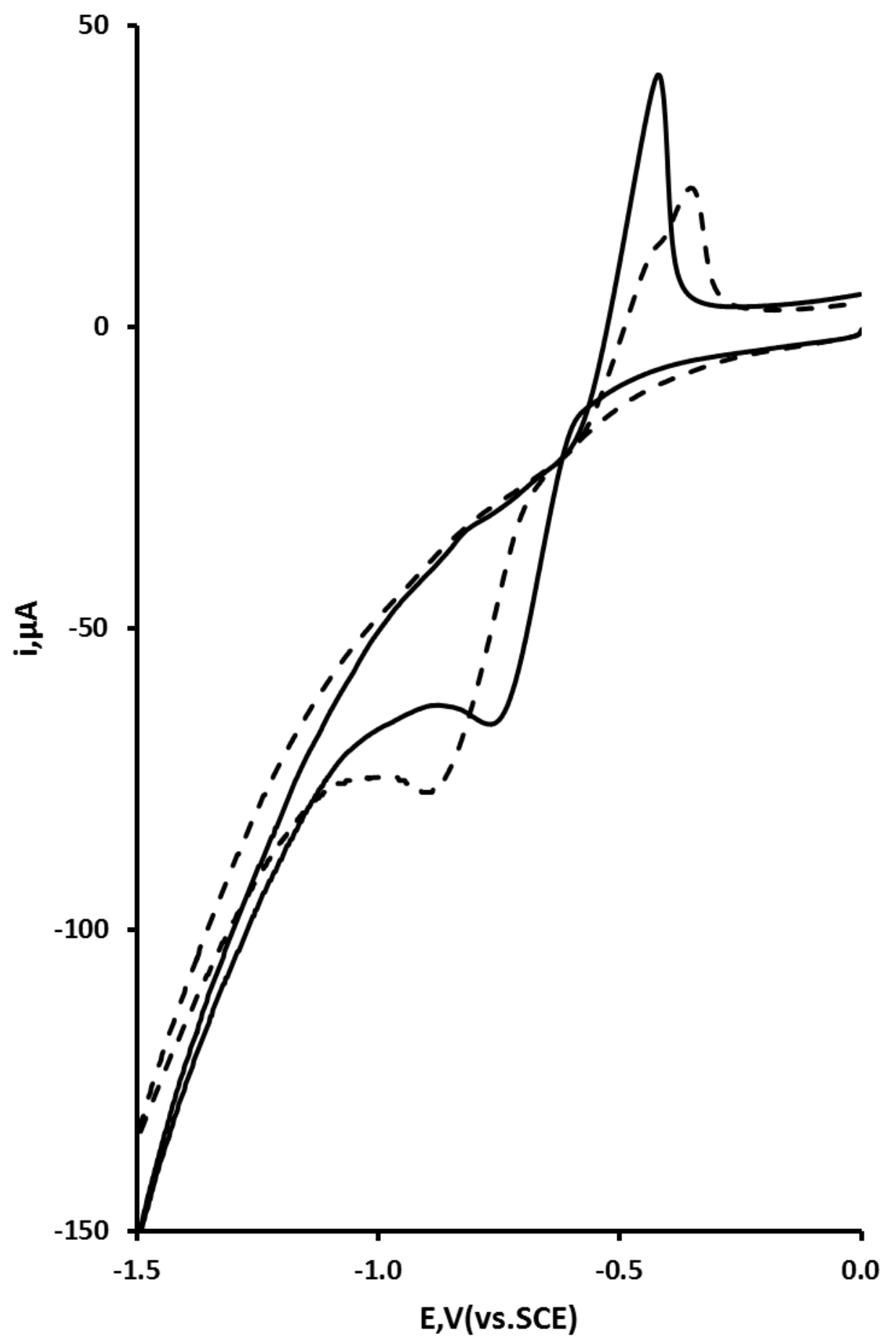

Figure 2. Cyclic voltammetric behaviour of $0.1 \mathrm{mM} \mathrm{Pb}$ at a drawn pencil in a $0.3 \mathrm{M}$ acetic acid solution in the presence (solid line) of $0.25 \mathrm{M} \mathrm{Cl}$ and in the absence of $\mathrm{Cl}$ (dashed line). Voltammetric conditions: starting and end potential $0.0 \mathrm{~V}$; switching potential $-1.5 \mathrm{~V}$; scan rate 50 $\mathrm{mV} / \mathrm{s}$. 


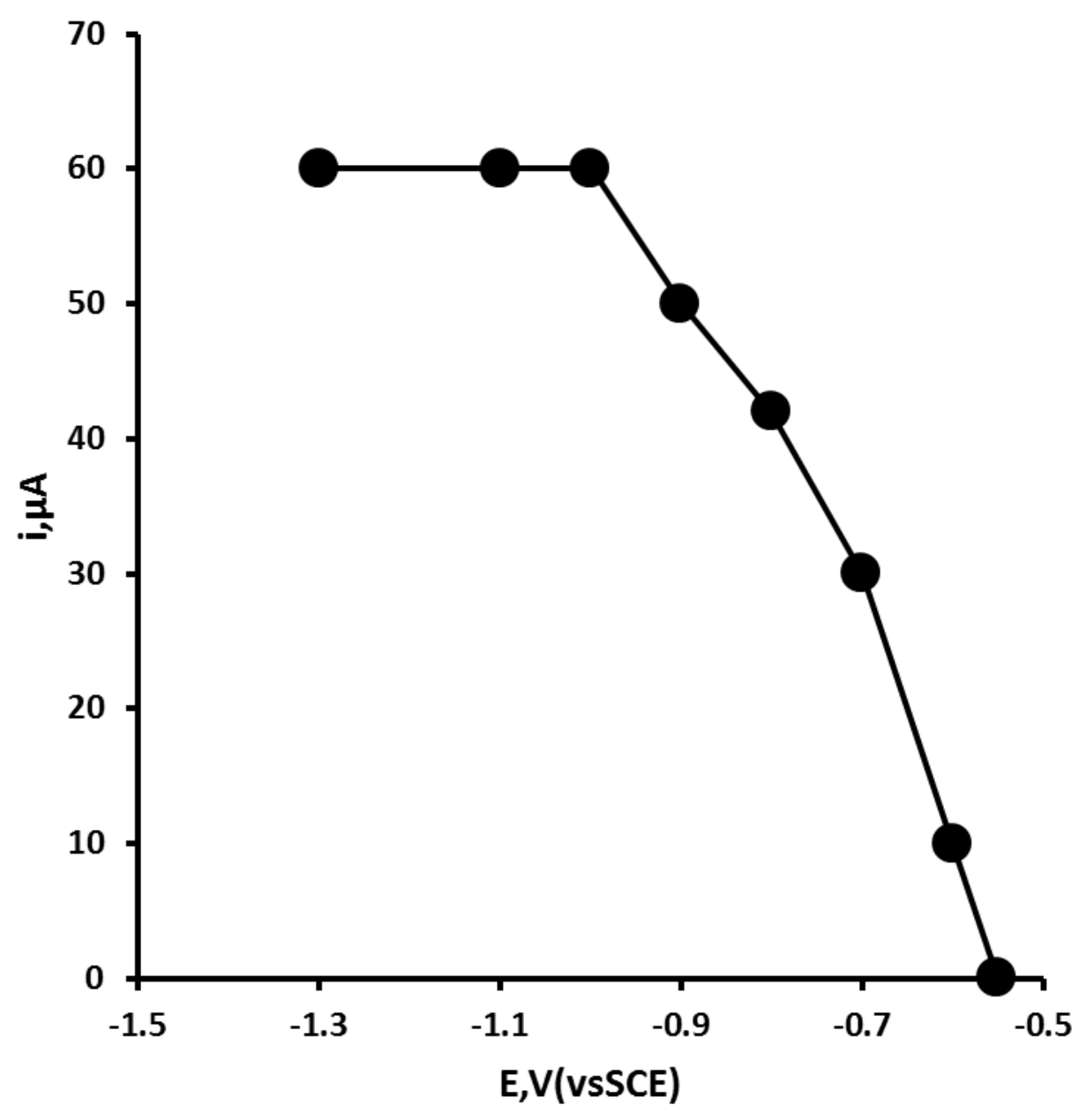

Figure 3. Effect of accumulation potential for a $0.1 \mathrm{mM} \mathrm{Pb}^{2+}$ solution in $0.3 \mathrm{M}$ acetic acid containing $0.25 \mathrm{M} \mathrm{KCl}$. Voltammetric conditions: Linear sweep stripping voltammetry, scan rate $50 \mathrm{mV} / \mathrm{s}$; end potential $0.0 \mathrm{~V}$. 

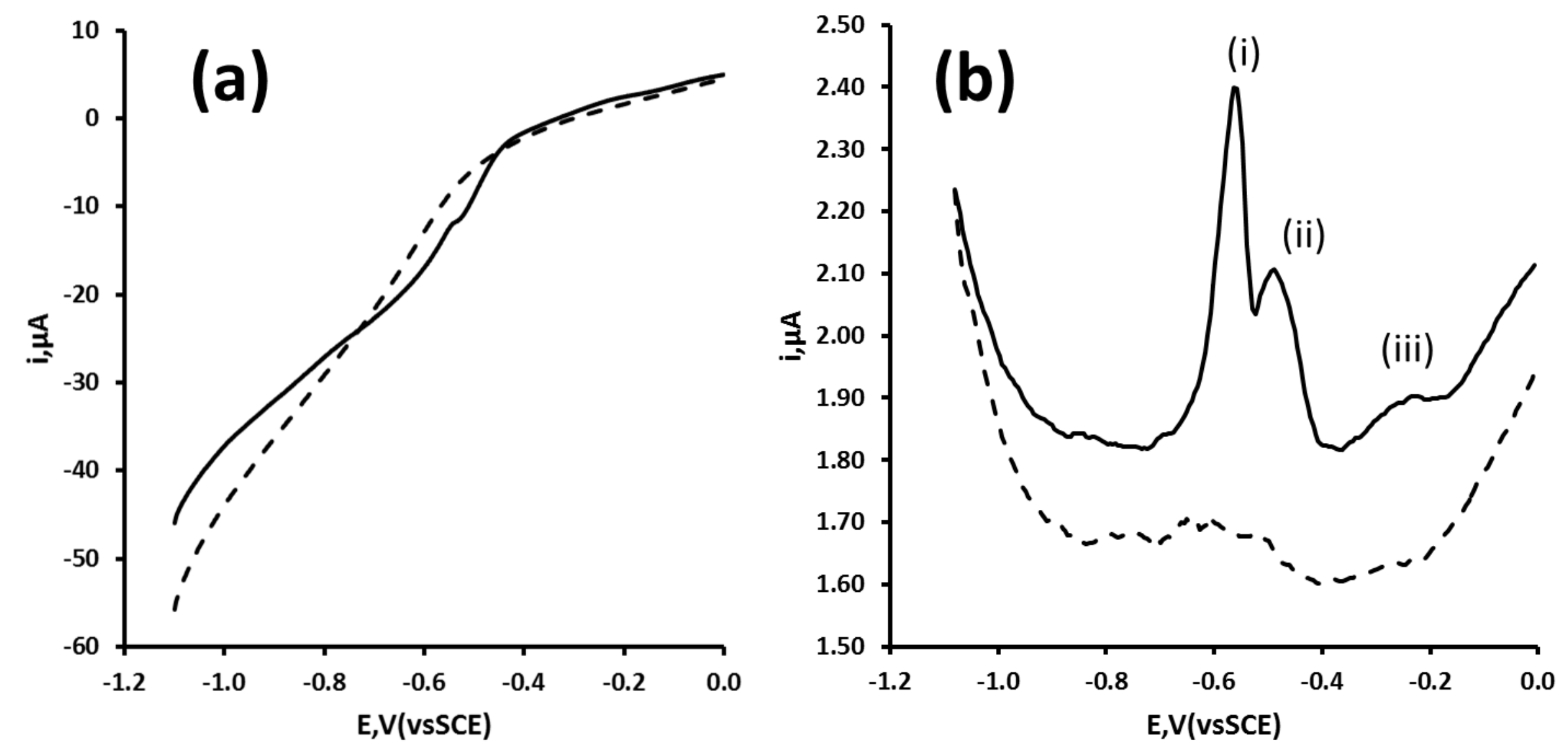

Figure 4. Effect of voltammetric waveform on the stripping voltammetric behaviour $\mathrm{Pb}$. Solid line, in the presence of $415 \mathrm{ng} / \mathrm{mL} \mathrm{Pb}$ and dashed line in the absence of $\mathrm{Pb}$. (a) linear sweep (b) differential pulse voltammetry. 


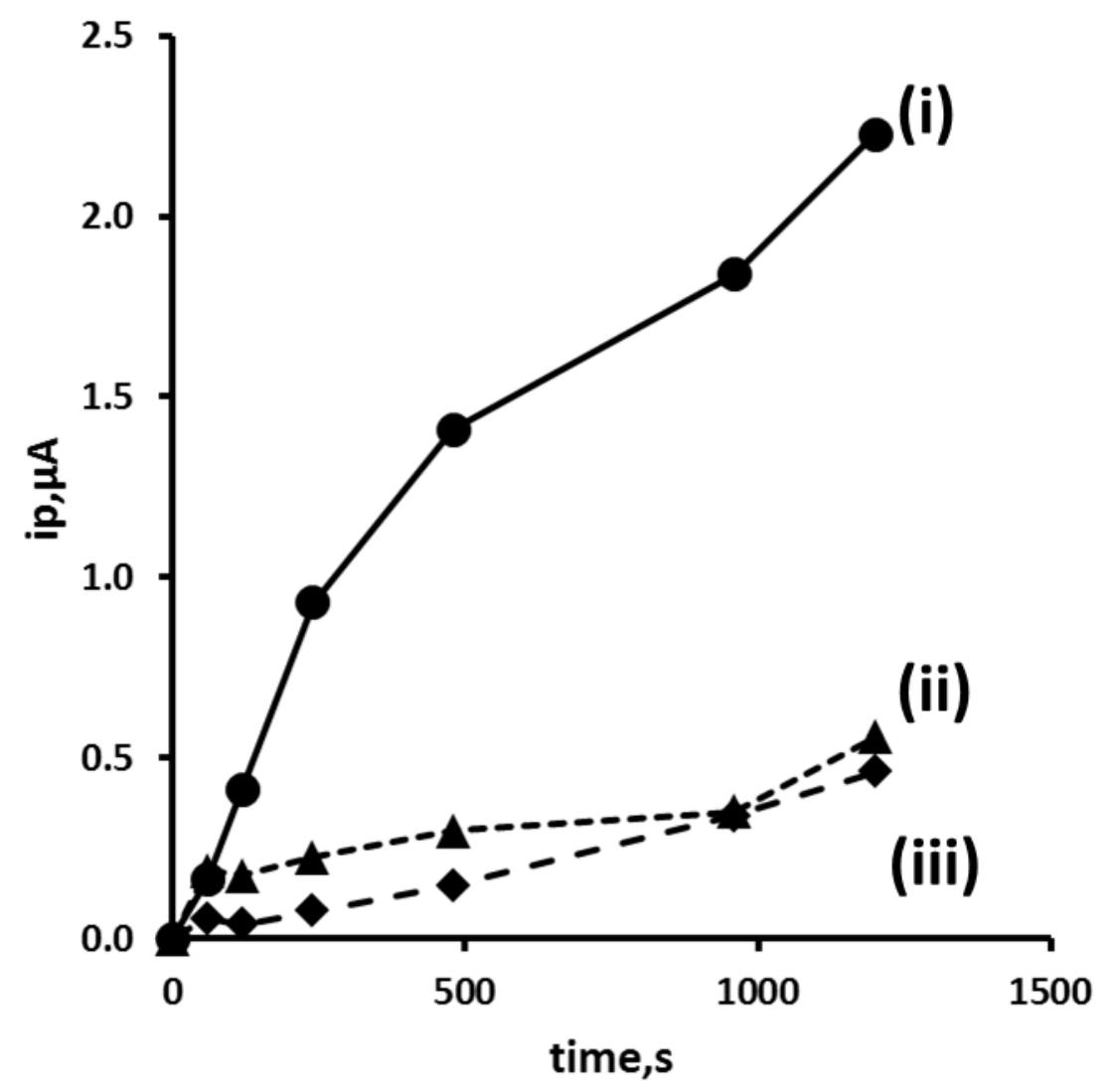

Figure 5. Effect of deposition time on the magnitude of stripping peak current for $\mathrm{Pb}$. Deposition potential and other conditions as Figure 3. 


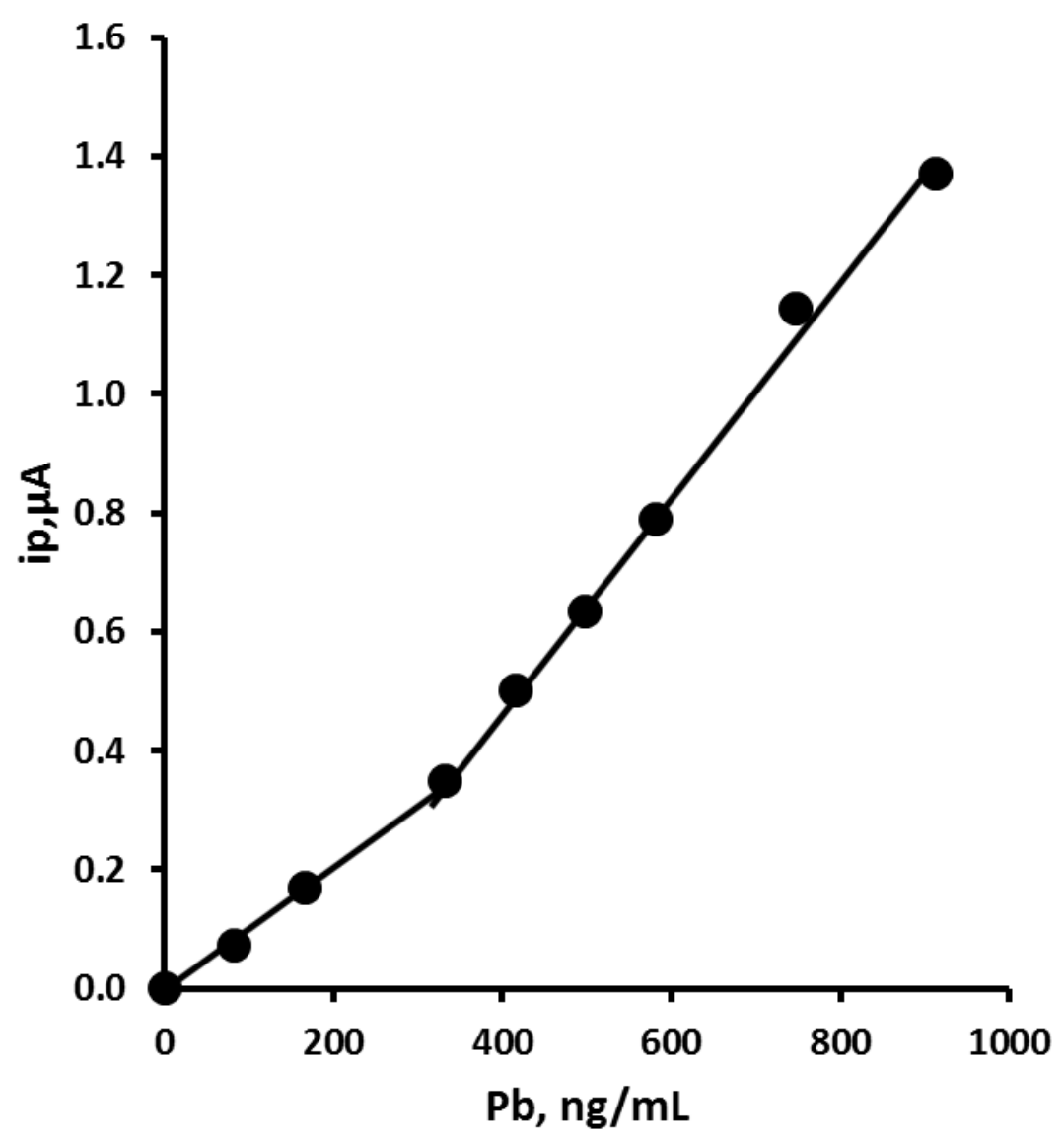

Figure 6. Calibration plot for Pb obtained by DPASV; supporting electrolyte $0.30 \mathrm{M}$ acetic acid, 0.25 $\mathrm{M} \mathrm{KCl}$. 


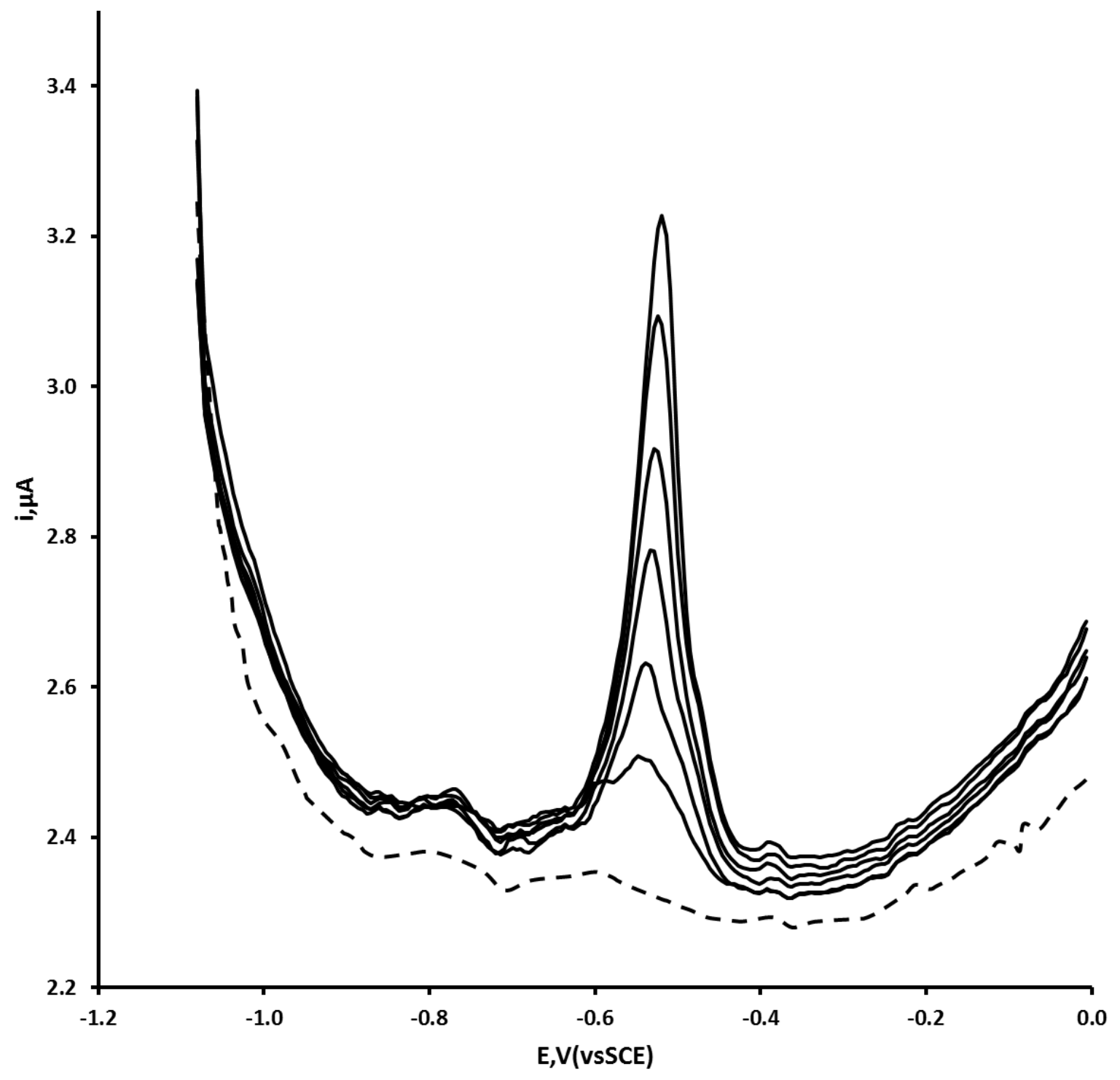

Figure 7. DPASVs of a representative drainage water sample spiked with $166 \mathrm{ng} / \mathrm{mL} \mathrm{Pb}$ with added concentrations of $\mathrm{Pb}: 0 \mathrm{ng} / \mathrm{mL} ; 83.0 \mathrm{ng} / \mathrm{mL} ; 116 \mathrm{ng} / \mathrm{mL} ; 249 \mathrm{ng} / \mathrm{mL} ; 332 \mathrm{ng} / \mathrm{mL} ; 415 \mathrm{ng} / \mathrm{mL} \mathrm{Pb}$ added. Dashed line representative DPASV of unfortified drainage water sample. Accumulation time: 200 s, deposition potential: $-1.1 \mathrm{~V}$ (vs. SCE). 


\begin{tabular}{|c|c|c|c|c|}
\hline & $\begin{array}{c}\text { Original Concentration } \\
{[\mathrm{ng} / \mathrm{mL}]}\end{array}$ & Added [ng/mL] & Found [ng/mL] & \% Recovery \\
\hline 1 & nd & 166.1 & 168.0 & 101.1 \\
\hline 2 & nd & 166.1 & 166.0 & 99.9 \\
\hline 3 & nd & 166.1 & 155.3 & 93.5 \\
\hline 4 & nd & 166.1 & 182.3 & 109.7 \\
\hline 5 & nd & 166.1 & 166.0 & 99.9 \\
\hline & & & mean & 100.9 \\
\hline & & & $\mathrm{sd}$ & 5.8 \\
\hline & & & $\% \mathrm{CV}$ & 5.7 \\
\hline
\end{tabular}

Table 2. Recovery and precision data for $\mathrm{Pb}$ obtained on drainage water samples, nd $=$ not detected. 


\section{References}

[1] K. Kalcher, I Švancara, R. Metelka, K. Vytřas, A. Walcarius, in Encyclopaedia of Sensors, Vol. 4, Crimes, G. A.; Dickey, E. C.; Pishko, M. V. Ed, American Scientific Publishers, Los Angeles, 2006; pp 283-429.

[2] H. E. Zittel, F. J. Miller, Anal. Chem. 1965, 37, 200-203.

[3] K. Vytřas, I. Švancara, R. Metelka, J. Serb. Chem. Soc. 2009, 74, 1021-1033.

[4] K. C. Honeychurch, Insciences J. 2012, 2, 1-51.

[5] A. M. Bond, P. J. Mahon, J. Schiewe, V. Vicente-Beckett, Anal. Chim. Acta 1997, 345, 6774.

[6] D. King, J. Friend, J. Kariuki, J. Chem. Ed. 2010, 87, 507-509.

[7] J. K. Kariuki, J. Electrochem. Soc. 2012, 159, H747-H751.

[8] N. Chauhan, J. Narang, C. Pundir, Am. J. Anal. Chem. 2010, 2, 41-46.

[9] D. Demetriades, A. Economou, A. Voulgaropoulos, Anal. Chim. Acta 2004, 519, 167-172.

[10] K. Pokpas, S. Zbeda, N. Jahed, N. Mohamed, P. G. Baker, E. I. Iwuoha, Int. J. Electrochem. Sci. 2014, 9, 736-759.

[11] M. Vestergaard, K. Kerman, E. Tamiya, Anal. Chim. Acta 2005, 538, $273-281$.

[12] Y. W. Hartati, S. Topkaya, I. P. Maksum, M. Ozsoz, Ad. Anal. Chem. 2013, 3A, 20-27.

[13] M. Cousta Sousa, J. W. Buchanan, Comput. Graph. Forum 2000, 19, 27-49.

[14] N. Kurra, G. U. Kulkarni, Lab Chip 2013, 13, 2866-2873.

[15] N. Dossi, R. Toniolo, A. Pizzariello, F. Impellizzieri, E. Piccin, G. Bontempelli, Electrophoresis 2013, 34, 2085-2091.

[16] M. Santhiago, L. T. Kubota, Sensor. Actuat. B-Chem. 2013, 177, 224-230.

[17] N. Dossi, R. Toniolo, E. Piccin, S. Susmel, A. Pizzariello, F. Impellizzieri, G. Bontempelli, Electroanalysis 2013, 25, 2515-2522.

[18] M. Santhiago, C. S. Henry, L. T. Kubota, Electrochim. Acta 2014, 130, 771-777.

[19] D. C. Bellinger, K. M. Stiles, H. L. Needleman, Pediatrics 1992, 90, 855-861.

[20] R. L. Canfield, C. R. Henderson, Jr, D. A. Cory-Slechta C. Cox T. A. Jusko, B.P. Lanphear, N. Engl. J. Med. 2003, 348, 1517-1526.

[21] J. Schwartz, D. Otto, Arch. Environ. Health 1987, 42, 153-160.

[22] M. Lustberg, E. Silbergeld, Arch. Intern. Med. 2002, 162, 2443-2449.

[23] B. K. Lee, G. S. Lee, W. F. Stewart, K. D. Ahn, D. Simon, K.T. Kelsey, A. C. Todd, B. S. Schwartz, Environ. Health Perspect. 2001, 109, 383-389.

[24] L. Giaccio, D. Cicchella, B. De Vivo, G. Lombardi, M. De Rosa, J. Geochem. Explor. 2012, 112, 218-225.

[25] H. A. Godwin, Curr. Opin. Chem. Biol. 2001, 5, 223-227.

[26] M. Loef, L. F. Mendoza, H. Walach, Toxin Reviews 2011, 30, 103-114.

[27] P. L. McCall, K. C. Land; Soc. Sci. Res. 2004, 33, 339-359.

[28] P. B Stretesky, M. J. Lynch, Arch. Paediatr. Adol. Med. 2001, 155, 579-582.

[29] A. C. Bautista, B. Puschner, R. H. Poppenga, J. Med. Toxicol. 2014, 10, 311-315.

[30] A. R. Flegal, D. R. Smith, N. Engl. J. Med. 1992, 326, 1293-1294.

[31] L. H. Hecker, H. E. Allen, B. D. Dinman, J. V. Neel, Arch. Environ. Health 1974, 29, $181-$ 185.

[32] E. Aparecida Silveira, F. Dayse Magalhães Siman, T. de Oliveira Faria, M. Vinícius Altoé Vescovi, L. Barros Furieri, J. Hott Fúcio Lizardo, I. Stefanon, A. Simão Padilha, D. Valentim Vassallo, Free Radic. Biol. Med. 2014, 67, 366-376.

[33] B. P. Lanphear, K. Dietrich, P. Auinger, C. Cox, Public Health Rep. 2000, 115, 521-529.

[34] R. L. Canfield, C. R. M. A. Henderson, Jr. D. A. Cory-Slechta, C. Cox, T. A. Jusko, B. P. Lanphear, N. Engl. J. Med. 2003, 348, 1517-1526.

[35] R. M. Delgado, J. Parsons, H. Garcia, A. A. Y. J. G. Corral, T. A. Cruz, Campos, M. A. Duarte, J. Gardea-Torresdey, Phys. Review Res. Inter. 2011, 1, 29-44.

[36] J. Y. Cabon, Spectrochim. Acta B 2002, 57, 513-524.

[37] F. Vydra, K. Štulik, E. Juláková, Electrochemical Stripping Analysis, Ellis Horwood, 1976.

[38] C.-W. Lin, Z. Zhao, J. Kim, J. Huang, Sci. Rep. 2014, 4, 3812. 
[39] T.K. Kang, Appl. Phys. Lett. 2014, 104, 073117.

[40] N. Dossi, R. Toniolo, F. Impellizzieri, G. Bontempelli, J. Electroanal. Chem. 2014, 722-723, 90-94.

[41] N. Dossi, R. Toniolo, F. Terzi, F. Impellizzieri, G. Bontempelli, Electrochim. Acta 2014, 146, 518-524.

[42] H. Yang, Q. Kong, S. Wang, J. Xu, Z. Bian, X. Zheng, C. Ma, S. Ge, J. Yu, Biosens. Bioelectron. 2014, 61, 21-27.

[43] K. C. Honeychurch, S. Al-Berezanchi, J. P. Hart, J. P. Talanta 2011, 84, 717-723.

[44] G. Carreño, E. Sosa, I. González, C. Ponce-de-León, N. Batina, M. T. Oropeza, Electrochim. Acta 1999, 44, 2633-2643.

[45] C. Ponce de-León, D. Pletcher, Electrochim. Acta 1996, 41, 533-541.

[46] K. C. Honeychurch, J. P. Hart, D. C. Cowell, Electroanalysis 2000, 12, 171-177.

[47] S. P. Perone, Anal. Chem. 1963, 35, 2091-2094.

[48] R. Ullah, R.N. Malik, A. Qadir, Afr. J. Environ. Sci. Technol. 2009, 3, 429-446.

[49] S. Khan, I.A. Shah, S. Muhammad, R.N. Malikc, M.T. Shah, Hum. Ecol. Risk Assess. 2015, 21, 10201031.

[50] F. Arduini, J. Q. Calvo, A. Amine, G. Palleschi, D. Moscone, TrAC, 2010, 29, 1295-1304.

[51] Z. Bi, P. Salaün, C. M. G. van den Berg, Electroanalysis 2013, 25, 357-366.

[52] A. Bobrowski, M. Putek, J. Zarebski, Electroanalysis, 2012, 24, 1071-1078. 